\title{
Factors Affecting Pycnidium Production of Diaporthe citri on Detached Citrus Twigs
}

\author{
S. N. Mondal, Assistant in Plant Pathology, University of Florida, IFAS, Citrus Research and Education Center and \\ Department of Plant Pathology, Lake Alfred 33850; J. P. Agostini, Research Plant Pathologist, Instituto Naciónal de \\ Técnologia Agropecúaria, 3384 Montecarlo, Misiones, Argentina; and L. Zhang, Technical Assistant, and L. W. \\ Timmer, Professor, University of Florida, IFAS, Citrus Research and Education Center and Department of Plant Pa- \\ thology, Lake Alfred 33850
}

\begin{abstract}
Mondal, S. N., Agostini, J. P., Zhang, L., and Timmer, L. W. 2004. Factors affecting pycnidium production of Diaporthe citri on detached citrus twigs. Plant Dis. 88:379-382.

Melanose, caused by Diaporthe citri, produces black-to-reddish brown lesions on twigs, leaves, and fruit of citrus and reduces the external quality of fruit destined for the fresh market. Inoculum for infection is produced primarily in pycnidia formed on dead twigs, and conidia are dispersed by rainwater. In laboratory studies, the effect of moisture, temperature, twig size, and melanose severity on pycnidium production on detached twigs was investigated. Pycnidium production was greatest when twigs were soaked for 3 to $4 \mathrm{~h}$ on alternate days three times per week and the temperature was $28^{\circ} \mathrm{C}$. Production was greatest on twigs 3 to $5 \mathrm{~mm}$ in diameter and less on thinner or thicker twigs. Pycnidium production was related linearly to melanose severity on the twigs, and almost no pycnidia were produced on asymptomatic twigs. In the field, pycnidium production was greatest on detached, melanose-affected twigs placed in the canopy monthly during January to April than it was on twigs placed in the canopy during other months. The largest number of pycnidia was produced from May to August when fruit is most susceptible. The number of pycnidia produced was related significantly to degree-days above $20^{\circ} \mathrm{C}$ and weakly related to cumulative rainfall. Knowledge of inoculum production peaks may assist in timing of pruning and fungicide sprays.
\end{abstract}

Melanose, caused by Diaporthe citri F.A. Wolf (anamorph, Phomopis citri H. Fawc.), produces black-to-reddish brown, raised pustules on the leaves, twigs, and fruit of citrus trees (11). Lesions on the fruit reduce its marketability, but the disease does not usually affect yield. All citrus species are susceptible, but grapefruit and lemons are the most severely affected. Diaporthe citri is widespread through the citrus areas of the world and can cause serious damage to fresh fruit in most humid areas.

Most of the inoculum is produced in pycnidia on dead twigs in the grove $(5,11)$. Although the pathogen causes symptoms on leaves, twigs, and fruit, it is difficult to isolate from older lesions. The fungus does not produce pycnidia on any of the living tissues but sporulates extensively on dead twigs $(2,5,11,12)$. As the tree ages, more dead wood accumulates, and more conidia are produced. Melanose severity on fruit is

Corresponding author: L. W. Timmer

E-mail: 1wt@crec.ifas.ufl.edu

This research was supported by the Florida Agricultural Experiment Station and approved for publication as Journal Series No. R-09748.

Accepted for publication 8 December 2003.

Publication no. D-2004-0130-01R

(C) 2004 The American Phytopathological Society directly related to the age of the tree and the amount of dead wood present (2). The teleomorph is produced on older, larger, dead twigs (11). Ascospores are airborne and serve to disseminate the pathogen more widely but probably contribute little to the total inoculum supply.

Most melanose infection occurs from petal fall until early to mid-summer $(7,10,11)$. Grapefruit is susceptible until it reaches approximately 7 to $10 \mathrm{~cm}$ in diameter, which usually occurs around late June or early July in Florida. In some areas where the fruit grows more slowly, it may be susceptible for longer periods. In Florida and Texas, most of the infection occurs during periods of high rainfall during May to early July. Extended wetting periods and high temperatures are needed to damage the fruit severely $(1,5,7,10)$. The disease is usually controlled by two to four applications of strobilurins or copper fungicides (6). Most fungicides are primarily protectant and have little effect on inoculum production (9).

Although pycnidia are produced on dead twigs, little is known about the time required after twig death for pycnidia to form, the duration of production, or the environmental or other factors required for inoculum production. Information on the production of pycnidia during the year may assist in the timing of fungicide applications. Growers mechanically top trees to facilitate harvest and improve light penetration and hedge the trees to allow access for equipment. These practices leave considerable amounts of dead wood in the tree canopies, but the effect of these practices on inoculum production by this pathogen is unknown.

In this study, we investigated the effect of moisture, temperature, twig size, and melanose severity on the production of pycnidia under laboratory conditions. In the field, pycnidial production was observed on detached affected twigs placed in the tree canopy each month for 2 years. A preliminary report of this study has been published (3).

\section{MATERIALS AND METHODS}

Laboratory studies. General procedures. For all tests, grapefruit twigs with melanose symptoms were collected from mature grapefruit in a grove where no fungicides had been applied. Severely affected twigs were selected for the wetting, temperature, and twig size experiments, cut into $10-\mathrm{cm}$ long segments, and dried for at least 10 days in the laboratory at 24 to $26^{\circ} \mathrm{C}$ prior to initiation of the experiments. Twigs were placed in $20-\times 20$ $\mathrm{cm}$ mesh bags with openings of $1.0 \times 1.0$ $\mathrm{mm}$. Each replicate consisted of one bag of 10 twigs, and all treatments were replicated three times.

In all experiments, the number of mature pycnidia was determined every 2 weeks by placing twigs in humid chambers for $24 \mathrm{~h}$ and observing them for the presence of pycnidia under a stereoscopic microscope. The total number of pycnidia on each twig producing slimy spore masses or spore tendrils was counted every 2 weeks for 180 days. Data were expressed as the cumulative total numbers of mature pycnidia per treatment. Periodically, spore masses were collected and placed on microscope slides and observed for the presence of typical alpha and beta conidia of $P$. citri to verify the identity of the fungus (11).

Soaking experiments. Mesh bags containing twigs 2 to $4 \mathrm{~mm}$ in diameter were soaked for $1,2,3,4,6$, or $24 \mathrm{~h}$ three times weekly on alternating days to determine the effect of soaking duration on pycnidial production. Twigs were air-dried on the laboratory bench at 24 to $26^{\circ} \mathrm{C}$ between soaking treatments. 
Temperature effects. Mesh bags containing twigs with 100 to 200 melanose lesions were placed in incubators in the dark at 20, 24,28 , or $32^{\circ} \mathrm{C}$. Twigs at all temperatures were soaked for $4 \mathrm{~h}$ on alternate days, three times per week, and dried at the treatment temperatures between soakings.

Twig size. Twigs severely affected with melanose were collected, cut into $10-\mathrm{cm}$ lengths, and grouped according to twig diameter as follows: 2.0 to $3.0,3.1$ to 4.0 , 4.1 to $5.0,5.1$ to 6.0 , and $>6.0 \mathrm{~mm}$. After initial drying, the twigs in mesh bags were soaked for 3 to $4 \mathrm{~h}$ on alternate days three times per week and maintained on the laboratory bench at 24 to $26^{\circ} \mathrm{C}$ between soakings.

Melanose severity. Twigs 3.0 to $5.0 \mathrm{~mm}$ in diameter with varying degrees of melanose severity were cut into $10-\mathrm{cm}$ lengths and dried. Twigs were grouped as follows: $0=$ no melanose, $1=10$ to 50 lesions, $2=51$ to 100 lesions, $3=101$ to 150 lesions, $4=151$ to 200 lesions, and 5 $=>200$ lesions. Twigs were soaked 3 to $4 \mathrm{~h}$ on alternate days three times a week and maintained on the laboratory bench at 24 to $26^{\circ} \mathrm{C}$ between soakings.

Field studies. At monthly intervals during March 2001 to March 2003, twigs (3 to $4 \mathrm{~mm}$ in diameter) that were severely affected by melanose were collected, cut into $10-\mathrm{cm}$ lengths, placed in mesh bags, and placed in the canopy of a grapefruit tree in a grove near Lake Alfred, FL. Each monthly sample consisted of three bags of 10 twigs each. Around the middle of each month, all bags were returned to the laboratory and placed in a moist chamber for $24 \mathrm{~h}$. All mature pycnidia with exuded
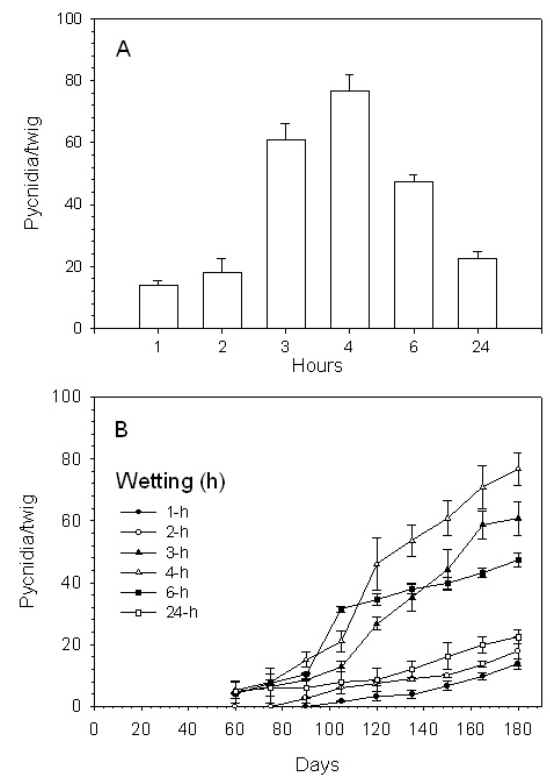

Fig. 1. Effect of soaking detached, melanoseaffected twigs from 1 to $24 \mathrm{~h}$, three times per week on pycnidium production of Diaporthe citri. A, Total pycnidial production for each treatment. B, Cumulative pycnidial production over time. spore masses or spore tendrils were counted and expressed as pycnidia per twig.

Weather data were retrieved from an automated weather station located within $500 \mathrm{~m}$ of the test site. Pycnidia production at 60,90 , and 120 days after placement of each sample in the grove was related to temperature and rainfall using regression analysis. Total rainfall and the degree-days above $20^{\circ} \mathrm{C}$ using average daily temperature were related to pycnidial production at different times.

Experimental design and data analysis. All laboratory experiments were conducted twice. Treatments were arranged in a completely randomized design with three replications per treatment. In most of the laboratory tests, the variance in the final number of pycnidia per twig was homogeneous between the two tests according to the two-tailed $F$ test, $P \leq 0.05$, and data were pooled for presentation. In one case where it was not, data from the two experiments are presented separately. Treatment effects were determined by analysis of variance using the GLM procedure in SAS (SAS Institute, Inc., Cary, N.C.). Cumulative pycnidia production was similar in both tests, and data from one test are presented. At each sample time, the average number of pycnidia per twig and the standard error of the mean were calculated.

\section{RESULTS}

Laboratory studies. Soaking time had a significant effect on total pycnidial production $(P<0.0001)$. Maximum pycnidial production was achieved with 3 to $4 \mathrm{~h}$ of soaking three times per week (Fig. 1A). Production began approximately 60 to 90 days after initiation of the experiment, but
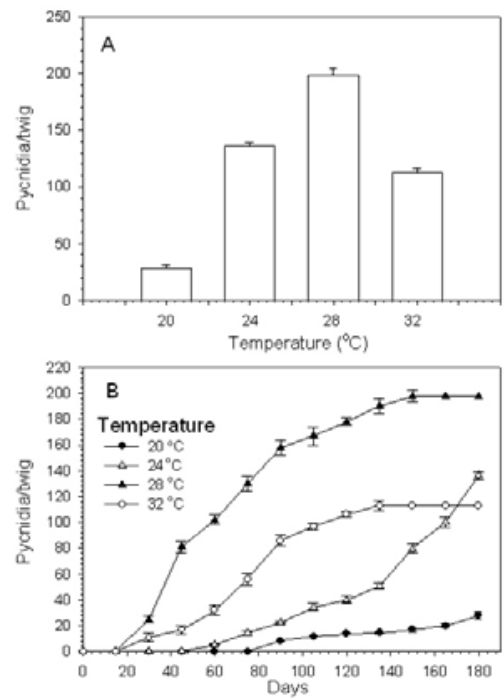

Fig. 2. Effect of temperature on pycnidium production of Diaporthe citri on detached, melanose-affected twigs soaked for $4 \mathrm{~h}$ three times per week. A, Total pycnidial production for each treatment. B, Cumulative pycnidial production over time. larger numbers were produced after approximately 120 days (Fig. 1B). Subsequently, 3-, 4-, and 6-h soak periods produced rapid increases in pycnidial production. The number of pycnidia produced in the 1-, 2-, and 24-h treatments remained low, even at 180 days.

Temperature was a significant factor affecting pycnidial production $(P<0.0001)$. The optimum temperature for pycnidial production was $28^{\circ} \mathrm{C}$ (Fig. 2A). Production at $24^{\circ} \mathrm{C}$ began slowly, but was still increasing at 180 days (Fig. 2B). At $32^{\circ} \mathrm{C}$, production of new pycnidia ceased after approximately 120 days. Some pycnidia were produced at $20^{\circ} \mathrm{C}$, but they developed very slowly.

Twig size had a significant effect on total pycnidial production $(P<0.0001)$. Maximum production of pycnidia occurred on twigs from 3 to $5 \mathrm{~mm}$ in diameter (Fig. 3A). The pattern of development of pycnidia with time did not differ greatly on twigs of different diameters (Fig. 3B). Pycnidia on twigs larger than $6 \mathrm{~mm}$ in diameter developed slowly and few were produced.

Melanose severity had a significant effect on pycnidial production $(P<0.0001)$. Production was greatest at the highest severity (Fig. 4A) and was linearly related to severity (adjusted $R^{2}=0.90$ in experiment 1 and 0.96 in experiment 2). Production was rapid on severely affected twigs, especially after 90 days (Fig. 4B). No pycnidia were produced on melanose-free twigs in one experiment, and pycnidia were rare in the other (Fig. 4B).

Field studies. Pycnidial production on melanose-affected, detached twigs placed
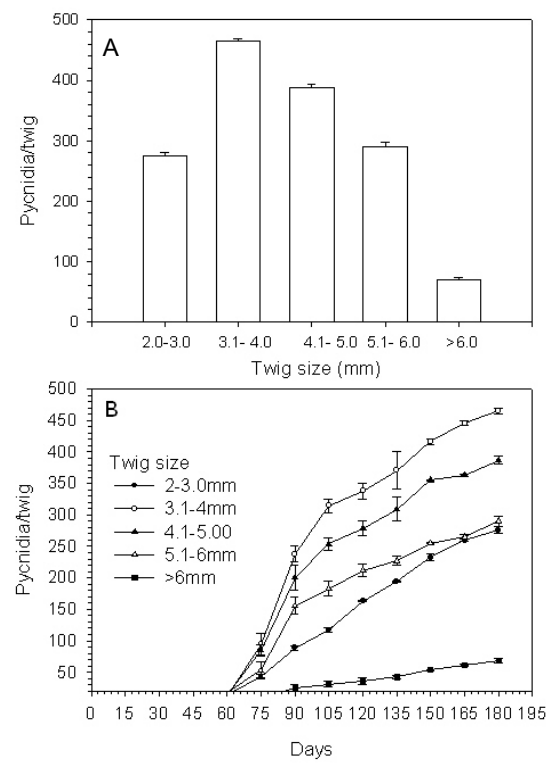

Fig. 3. Effect of twig diameter on pycnidium production of Diaporthe citri on detached, melanose-affected twigs soaked 3 to $4 \mathrm{~h}$ three times per week. A, Total pycnidial production for each treatment. B, Cumulative pycnidial production over time. 
in the tree canopy early in the year typically required 3 to 5 months (Fig. 5). Twigs placed in the grove during January to April produced large numbers of pycnidia, mostly from May to August. In contrast, twigs placed in the grove during May to September produced pycnidia in approximately 2 to 3 months, but the number produced was substantially lower. Twigs placed in the canopy in October produced no pycnidia until at least February, and the total number produced was low. Twigs placed in November and December eventually produced moderate numbers of pycnidia, but production was spread over a long period. The average number of pycnidia per twig produced on twigs present in the tree in both years during May to August was 51.2, but was only 16.8 during January to April, and was 21.1 during September to December.

Regression analysis of temperature with pycnidial production showed the production at 60,90 , or 120 days were significantly related to accumulated degree-days (Table 1). With rainfall, the relationship was significant at 60 days, but not at 90 or 120 days. Stepwise multiple regression analyses were conducted, but no combination of rainfall and temperature data explained significantly more of the variation than either factor alone.

\section{DISCUSSION}

Under optimal conditions, pycnidia of D. citri were produced on detached twigs in approximately 45 days. When severely affected twigs 3 to $5 \mathrm{~mm}$ in diameter were clipped from the tree, dried, incubated at $28^{\circ} \mathrm{C}$, and soaked for 3 to $4 \mathrm{~h}$ three times weekly, pycnidial production was maxi-
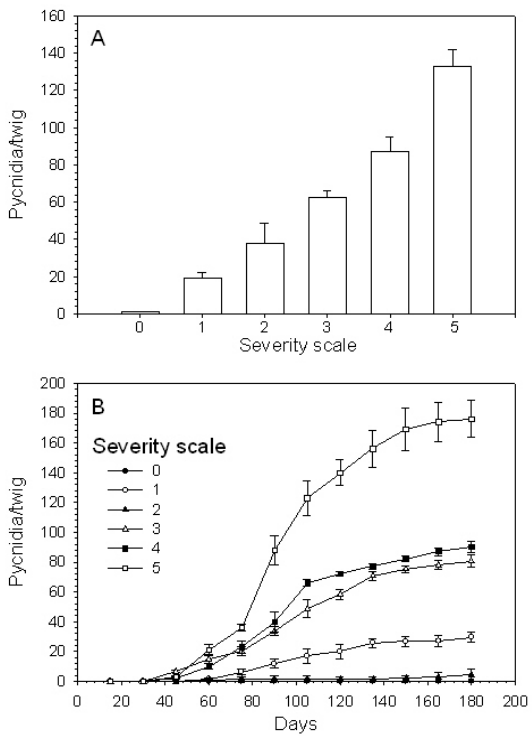

Fig. 4. Effect of melanose severity on the pycnidium production of Diaporthe citri on detached twigs soaked 3 to $4 \mathrm{~h}$ three times per week. A, Total pycnidial production for each treatment. B, Cumulative pycnidial production over time. mized. These procedures can be used for production of inoculum for experiments. We also found that these methods provide the most consistent means of isolating the pathogen. D. citri is difficult to isolate since it does not survive long in fruit or leaf lesions (11). It is most easily isolated
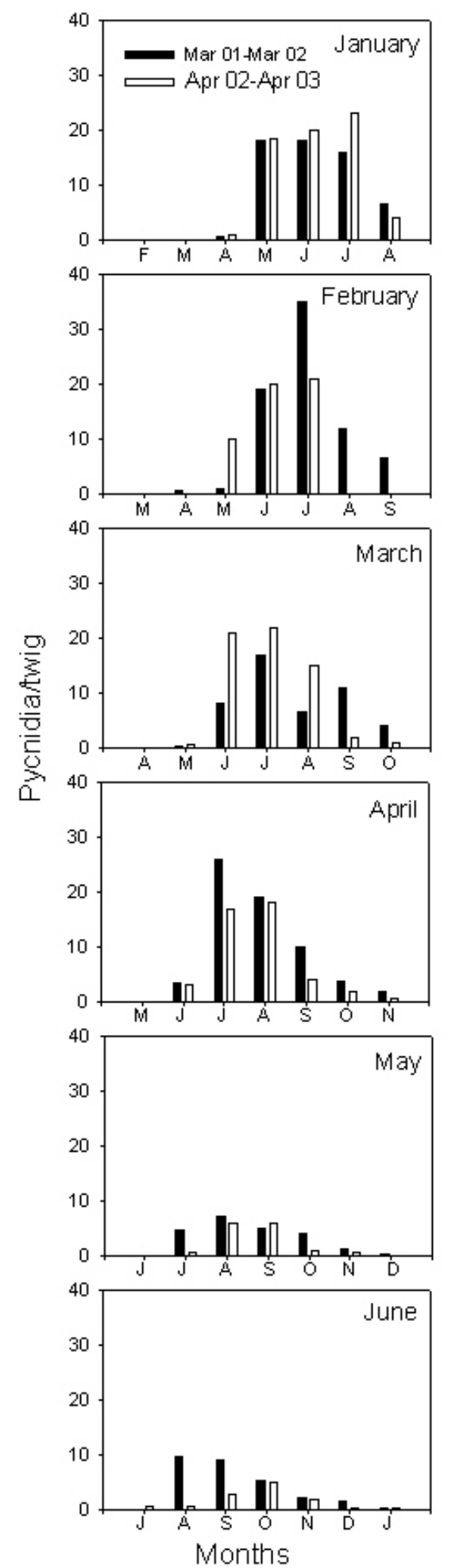

from fruit affected by Phomopsis stem-end rot. However, at some times of the year, such fruit may not be available. Although production of pycnidia on detached twigs requires some time, it provides the most consistent means of recovery of the pathogen. Once mature pycnidia are formed, bits

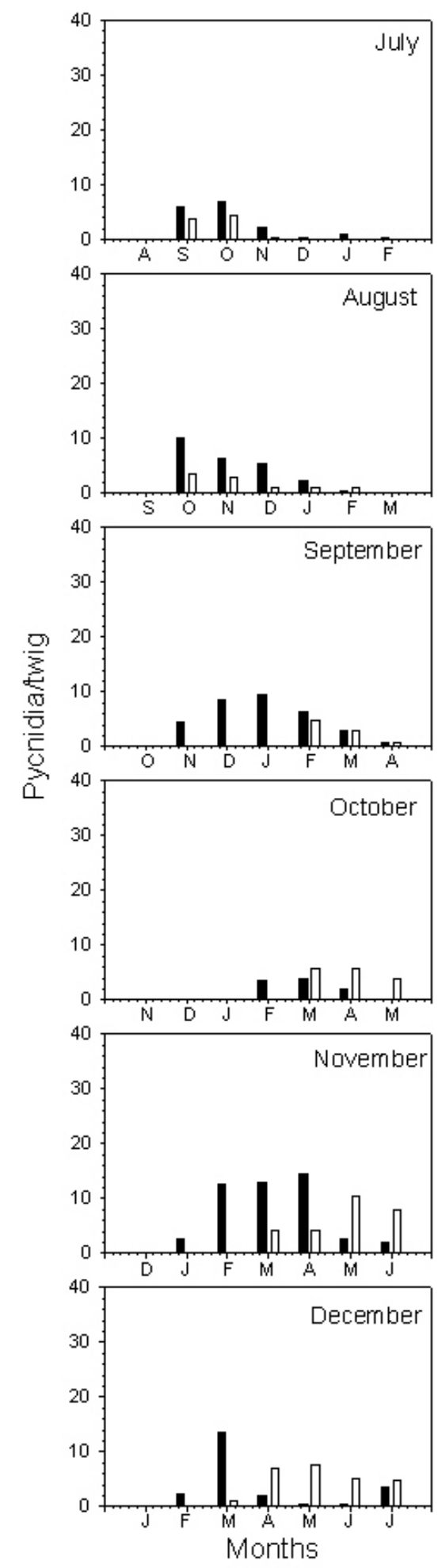

Fig. 5. Pycnidium production on detached, melanose-affected twigs placed in the grove each month during March 2001 to March 2003. Twigs were cut on the month indicated in the upper right corner of each graph, and pycnidial production was measured in the subsequent months. 
Table 1. Linear regression analysis of temperature and rainfall with pycnidia production of Diaporthe citri on detached, melanose-affected twigs 60,90, and 120 days after placement in the tree canopy

\begin{tabular}{lccc}
\hline & Degree-days $^{\mathbf{a}}$ & & Rainfall (mm) \\
\cline { 2 - 2 } Time after exposure of twigs & $\boldsymbol{R}^{\mathbf{2}}$ & $0.32^{* * \mathrm{c}}$ & $\boldsymbol{R}^{\mathbf{2}}$ \\
\hline 60 days & $0.15^{*}$ & $0.19^{*}$ \\
9 days & $0.37^{* *}$ & $0.13 \mathrm{~ns}$ \\
120 days & $0.08 \mathrm{~ns}$ \\
\hline
\end{tabular}

${ }^{a}$ Degree-days were calculated using average daily temperature with a base of $20^{\circ} \mathrm{C}$.

${ }^{\mathrm{b}}$ Detached, melanose-affected twigs $10-\mathrm{cm}$ long and 2 to $4 \mathrm{~mm}$ in diameter were placed in the tree canopy monthly during March 2001 to March 2003.

$\mathrm{c} * * *$, and $\mathrm{ns}=$ significant at $P \leq 0.05,0.01$, or not significant, respectively.

of spore tendrils can be aseptically transferred to any of the common cultural media for isolation.

In the laboratory and the grove, pycnidial production usually required 45 to 60 days under warm conditions and from 90 to 120 days at cooler temperatures. On detached twigs in the laboratory, production ceased after approximately 6 months. At lower than optimum temperature, production was slower and probably would continue longer. Thus, in cooler climates, the duration of pycnidial production is longer, and disease may be more severe than in warmer climates.

In our study, pycnidial production was greatest on small twigs, as was noted by other investigators $(2,4,12)$. There was some evidence of interactions between wetting duration and twig thickness. Pycnidial production was low on twigs $>6$ $\mathrm{mm}$ in diameter when soaked for 3 to $4 \mathrm{~h}$, but pycnidial production could be greater if soaked longer. In contrast, pycnidial production might be greater if small twigs were soaked for shorter times. Wetting twigs frequently and for long periods causes rapid decay, which does not allow time for pycnidia to form. It has been observed that melanose is not a severe problem in more humid, tropical areas, probably because of the rapid rate of decay of twigs (5).

The severity of melanose is closely related to tree age and the amount of dead wood in the trees (2). Thus, removal of dead twigs might be expected to be a useful control measure. Ruehle and Kuntz (4) found that pruning was sometimes helpful but was unreliable as a control measure. Spraying with copper fungicides was much more effective. Most of the inoculum is produced on small twigs that have died in the last 6 months, and such material is difficult to remove in a timely fashion.

Dead wood left in the tree canopy after hedging and topping is probably not a large source of inoculum. Most of the wood removed is on the top and outside of the tree. These twigs are not likely to be affected by melanose. This study showed that very few pycnidia are formed on asymptomatic twigs. Thus, it does not appear that D. citri forms latent infections on twigs. Growers that are concerned can hedge and top groves of early cultivars from November to December. In that way, pycnidial production would be low by the time the new crop of susceptible fruit is set in April. On late cultivars, hedging and topping could be conducted in May or June. Then fruit would already be resistant by the time pycnidia formed.

Pycnidial production is generally high at the time of year when fruit is most susceptible, that is, from April until early July. The average number of pycnidia per twig was 30, 37, 59, and 95 in April, May, June, and July, respectively. Environmental conditions for infection are least favorable in April in Florida (10) and most favorable in June and early July. It would also appear that inoculum pressure is lowest in April and higher later. This work supports earlier studies and recommendations that fungicide application intervals can be increased early in the season but should be shortened later in the season (8).

\section{LITERATURE CITED}

1. Agostini, J. P., Bushong, P. M., Bhatia, A., and Timmer, L. W. 2003. Influence of environmental factors on the severity of citrus scab and melanose. Plant Dis. 87:1102-1106.

2. Davis, R. M., and Wilhite, H. S. 1983. Relationships between melanose incidence and dead wood in Texas grapefruit. J. Rio Grande Val. Hortic. Soc. 36:41-49.

3. Mondal, S. N., Agostini, J. P., and Timmer, L. W. 2003. Factors affecting pycnidial development of Diaporthe citri, the cause of citrus melanose. (Abstr.) Phytopathology 93(suppl.): S563.

4. Ruehle, G. D., and Kuntz, W. A. 1940 Melanose of citrus and its commercial control. Florida Agric. Exp. Stn. Bull. 349. University of Florida, Gainesville.

5. Timmer, L. W. 1999. Diseases of fruit and foliage. Pages 107-115 in: Citrus Health Management. L. W. Timmer and L. W. Duncan, eds. The American Phytopathological Society, St. Paul, MN.

6. Timmer, L. W., ed. 2003. 2003 Florida Citrus Pest Management Guide. Univ. Florida Coop., Ext. Serv., Univ. Florida, Gainesville. Publ. No. SP-43.

7. Timmer, L. W., and Fucik, J. E. 1976. The relationship of rainfall distribution, fruit growth and fungicide application to the incidence of melanose of grapefruit in Texas. Plant Dis. Rep. 60:565-568.

8. Timmer, L. W., Zitko, S. E., and Albrigo, L. G. 1998. Split application of copper fungicides improve control of melanose on grapefruit in Florida. Plant Dis. 82:983-986.

9. Whiteside, J. O. 1977. Sites of action of fungicides in the control of citrus melanose. Phytopathology 67:1067-1072.

10. Whiteside, J. O. 1980. Timing of fungicide spray treatments for citrus melanose control. Proc. Florida State Hortic. Soc. 93:21-24.

11. Whiteside, J. O. 2000. Melanose. Pages 28-29 in: Compendium of Citrus Diseases. 2nd ed. L. W. Timmer, S. M. Garnsey, and J. H. Graham, eds. The American Phytopathological Society, St. Paul, MN.

12. Winston, J. R., Bowman, J. J., and Bach, W. T. 1927. Citrus melanose and its control. U.S Dep. Agric. Bull. 1474. 